
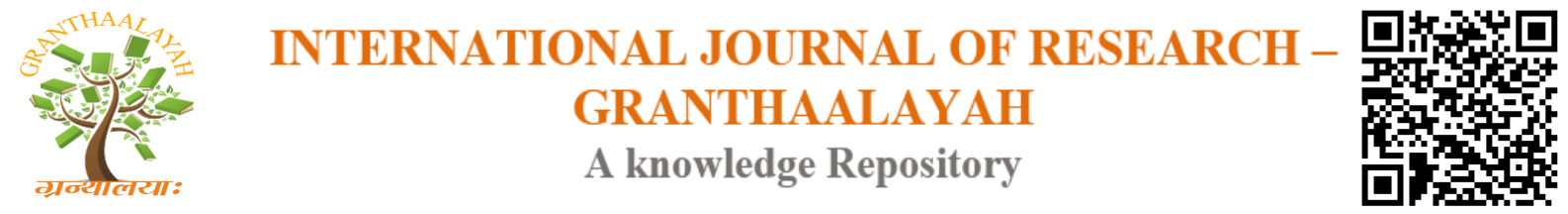

Management

\title{
UNDERSTANDING AND COMMUNICATING THE CONCEPT OF CORPORATE SOCIAL RESPONSIBILITY - A STUDY OF 23 INDIAN COMPANIES IN EASTERN INDIA
}

\author{
Dr. Enakshi Sengupta ${ }^{1}$, Vijay Kapur ${ }^{2}$ \\ ${ }^{1,2}$ Assistant Professor, American University of Kurdistan, NORTHERN IRAQ
}

DOI: https://doi.org/10.29121/granthaalayah.v4.i6.2016.2635

\section{ABSTRACT}

The Companies Act 2013 in India with its mandate for CSR has formally introduced the concept of CSR to the board of Indian companies. The practice of CSR, although bordering on charity giving, is not a new idea to India. The critical situation that India is facing today has been brought about by multiple causes. Corporate bodies are the fundamental cells of modern economic life and should work towards affirming values and forging new patterns of living and better working conditions. Corporate's should play a vital role towards contributing to the continuing health of the planet and to develop a just and humane society. The crisis faced by humanity today can be solved by the use of concerted corporate actions. Corporations are instruments of social purposes, formed within the society to accomplish useful social objectives. What the companies need to understand is the intention of this Act to undertake CSR activities which are systematic and strategic in nature to create a meaningful impact for the companies. Research was conducted among 23 Indian companies in Eastern India in the private sector engaged in manufacturing and heaving engineering. The authors developed a scorecard consisting of 46 criteria which was used to study the CSR activities of these companies as declared in their websites and in other published sources. The intention was to find out the complexity of the perception-practice dynamic and the nature of CSR practised by the companies. In-depth qualitative interview was conducted with the top management of the company giving a further insight into their understanding of the concept of CSR.

Keywords:

Corporate Social Responsibility, Stakeholder theory, Strategic CSR, Corporate Reputation, Corporate Legitimacy, Sustainability Report.

Cite This Article: Dr. Enakshi Sengupta, and Vijay Kapur, "UNDERSTANDING AND COMMUNICATING THE CONCEPT OF CORPORATE SOCIAL RESPONSIBILITY - A STUDY OF 23 INDIAN COMPANIES IN EASTERN INDIA" International Journal of Research - Granthaalayah, Vol. 4, No. 6 (2016): 46-54. 


\section{INTRODUCTION}

The concept of 'corporate social responsibility' (CSR) in its modern day terminology started gaining ground in the last 15 years or so. Corporate misbehaviour or scandals were partly responsible for this growing consciousness. Enron and Arthur Anderson scandal, Shell's Brent Spar case and others led to major scepticism and decrease of trust in large corporations. On one hand the century witnessed the growing power of the corporations and a market caught up in the whirlwind of rapid transition due to privatization, liberalization and globalization. On the other hand the world has witnessed issues related to accountability and transparency posed by stakeholders of these corporations. With the growth of social media platforms the flow of information is almost constant and immediate and every move of the corporation is on public display almost instantaneously.

In this era of heightened social expectations there are a number of international bodies who have set standards of communication for corporations. In Europe alone the corporate environment is experiencing a gradual shift from implicit to explicit corporate behaviour which is ushering in new challenges as well as opportunities for corporations as to how to communicate their CSR activities (Matten \& Moon 2004). In India there has been a paradigm shift towards explicit CSR which demands greater visibility with a voluntary approach along with self-interest driven policies and strategies that are perceived by the company's stakeholders as meaningful. Beckman et. al (2006) agrees that the 'silent strategy' once practiced by companies are giving way to CSR communication and is becoming a part of a company's communication strategy needed to gain a competitive advantage.

Corporate motives are being increasingly questioned and come under scrutiny from activists, critical journalists and consumer groups who test the validity of corporate claims (Morsing 2006). A large number of corporates are joining the battle of attention. Corporations have a hard task ahead of trying to prove to their stakeholders and sceptic audience that they are as good as they claim.

This paper investigates with its primary focus towards Indian companies in eastern India the level of engagement of companies towards their stakeholders by communicating their CSR activities. The purpose of this paper is to summarize the findings and discuss the corporate motives for engaging in CSR communication and the instrumental value of the corporate brand in strategic CSR communication. This paper shall also highlight the appropriateness and the legitimacy of the methodological choices on which this research is based.

\section{LITERATURE REVIEW}

The 1990's saw the debate over CSR being accelerated and more than hundred definitions were formulated to explain the concept of CSR (Carroll 1999). The concept of CSR is undergoing change and is perceived differently in different cultural context depending upon the growth and development of that particular nation. This paper is not about highlighting the definitions of CSR and interpreting its various meaning. This study concerns with two aspects of CSR - the stakeholder theory and the motivation towards CSR communication. 


\subsection{STAKEHOLDER THEORY}

Edward Freeman the originator of the stakeholder concept suggested that the term 'corporate social responsibility' should be replaced by the term 'company stakeholder responsibility'. He argued that the main objective of CSR is to create value for key stakeholders and fulfil responsibilities towards these groups (Freeman 2006). Freeman's view on CSR is normative because he proposes that a stakeholders approach to CSR is the right thing to do. He further points out that corporation are not capable of generating profits without a broader engagement with stakeholders. Freeman defines stakeholders as 'any group or individual who is affected by or can affect the achievement of an organization's objectives (Freeman 1984).

Businesses are viewed as a connection of stakeholders approach to CSR resulting in value creation. Engaging with stakeholders requires extensive dialogue with each other. In our study through the scorecard developed by the authors, the level of engagement of this dialogue and the process of two way communication between the company and its stakeholders were explored. There are various theories which have developed around Freeman's view on stakeholder engagement and these theories are relevant to contemporary society. Most of the research scholars in the field of CSR agree to the multiple stakeholder approach becoming a defining characteristic of corporate responsibility in the 21st century (Elkington 2001). Similarly the academicians and researchers also agree to the integrated approach to CSR into its corporate vision, values, strategies and organizational culture.

Corporations are expected to act in a more socially responsible manner if they engage in dialogue with their stakeholders. Interaction and repeated dialogue enhances the understanding and appreciation of the actor's concern (Campbell 2007).

\subsection{CSR AND COMMUNICATION}

In recent years CSR communication has become an inherent part of the corporate communication strategy. Researchers in this field have unveiled two basic motives for companies to communicate their CSR strategy. Companies communicate as they are driven by the need to imitate their peers or they are driven by the strategic benefit that they derive out of communicating their CSR activities. The main two benefits of strategic CSR communication are to gain 'corporate legitimacy' or to enhance 'corporate reputation'. Strategic legitimacy management relies heavily on the communication between the organization and its various stakeholders. Corporate reputation is a multi-dimensional construct that incorporates the unique dimension on which individual stakeholders base their judgement of their corporate performance (Fombrun, 2002). A good reputation of a company has a strategic value and the key ingredients of a good reputation lie in its visibility, transparency, distinctiveness, consistency and authenticity. The impact of corporate brands is arguable closely linked to CSR and corporations depend upon the support and approval it receives from its stakeholders for their activities (Schultz 2005).

Hatch and Schultz (2003) views corporate brand as constituting from three elements: strategic vision, organizational culture and corporate images. Vision deals with the organization and what the organisation wants to be. Culture is internal to that of the organization and communicating 
the meaning of the organisation to its members, and the images are the perception of the stakeholder groups about the organization. In regard to CSR communication the entire corporate brand identity is argued to function as a guiding beacon and sense making tool for aligning action and communication.

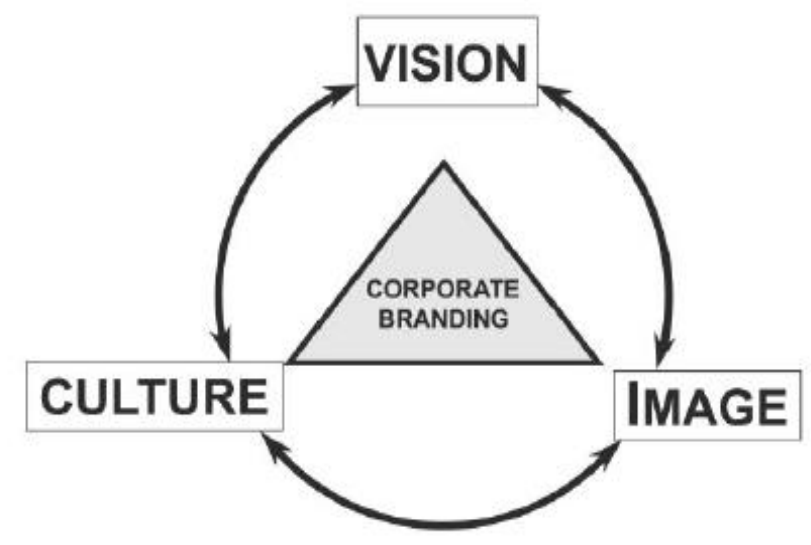

Foundation of Corporate Branding

Source: Hatch and Schultz, 2003.

The multidimensional nature of corporate image, its intangible aspects and reputational sustainability are being emphasized by CSR practitioners. The necessity for a holistic approach towards reputation management in the context of corporate social responsibility has been emphasized by scholars in this field. According to these theorists the organizational reputation unfolds all the visual, virtual, verbal and behavioural elements of an organization or a person. Therefore, it is imperative that the corporate reputation is built as a result of stakeholders interpretations of the same. Image and reputation is driven by the multitude or a plethora of both internal and external factors and they impinge heavily on image and reputation of the company. CSR communication is a vital component that is instrumental in building the corporate image and to withhold its reputation as a good corporate citizen. A favourable corporate reputation results in competing successfully amongst the competitors, achieving a familiar and positive image, building an ethical and transparent work culture with highly motivated employees, and communicating widely with various stakeholders (Fombrun and Van Riel, 2003). A positive organization reputation has found to influence purchase decisions when there is little difference in price, quality design and product. A positive corporate reputation creates a competitive advantage of the company having its definite impact on the triple bottom-line.

\subsection{THE INDIAN CONTEXT}

The concept of Corporate Social Responsibility is not new to India. It emerged from the "Vedic Era" when kings had an obligation towards society and merchants displayed their own business responsibility by building places of worship, education, inns and wells. Although the core function of business was to create wealth for society and was based on an economic structure, the business community with their rulers believed in the philosophy of "Sarva loka hitam" which means "the well-being of all stakeholders". The acceptance of social responsibility is redirecting Indians to their cherished values and teachings of their ancestors and their religious scriptures in 
the field of business. The National Voluntary Guidelines 2011 released by Ministry of Corporate Affairs, India was set up as part of the multi-stakeholder platform on CSR making it mandatory for companies to disclose their CSR projects. (http://www.gtz.de/en/weltweit/asienpazifik/indien/23977.htm).

"In a bid to turn companies' management decisions more transparent, the corporate affairs ministry may mandate more disclosures in their annual financial statements and the reports of boards of directors. The manner in which companies carried out their Corporate Social Responsibility (CSR) activities during the year will become part of the annual mandatory disclosure. The details of the policy adopted by the company, the way it was implemented and the result achieved will all be reflected in the report." (International Bar Association, CSR ebulletin, October, 2011).

CSR has taken a prominent role with the growth of globalization, liberalization and emerging free market economy. Foreign investors are vying for India more than ever before. With the growth of trade links between India and other countries CSR continues to be an important aspect in business. Companies can benefit from adopting corporate responsibility policies in response to globalization and these can be done through access of markets, cost and risk reduction, improving productivity, competitiveness and improving public image of companies (Dasgupta A, 2007). The journey of CSR in India is not a smooth ride, obstacles come in the form of ad-hoc approaches by the top management, and there is also a lack of consensus on priorities and agenda within the firm regarding CSR policies and programmes. There are no clear guidelines to measure and evaluate CSR activities accounting for the return of investments. Unclear policies, bureaucracy, poor monitoring, complicated tax systems, and poor infrastructure are a few more hindering factors in the field of CSR in India (CSM, 2001). Although the journey has begun but CSR in India is yet to be realized in its full potential. Individual and collaborative initiatives continue to be dominating the scene of CSR by self-assertion rather than accountability (Dasgupta A. 2008). There is certainly no dearth of innovative CSR activities and projects, but what is missing, are definite goals, embedding of a CSR culture and practice and metrics for evaluating their social impact in improving the plight of many. The codification of CSR activities remains highly descriptive and self-praising in nature, lacking the recording of actual facts and figures which can be measured vis-à-vis the money spent on these activities. India's markets continue to exhibit negative externalities and free riders where cost for destruction and degradation of environment and community is not accounted for which ultimately leads to socioeconomic degeneration.

\section{RESEARCH METHODOLOGY}

To find out how well this mandate of disclosing CSR activities is accepted by Indian companies the authors chose to study 23 companies belonging to private sector companies in Kolkata, India. These companies operate mainly in the manufacturing or heavy engineering sector. The nature of their business may often results in polluting the atmosphere or displacement of inhabitants. Data was collected from open sources and the published reports and websites of these companies were studied in detail. A Gap Analysis tool in the form of a score card was developed by the authors having 46 criteria which highlighted areas such as stakeholder engagement, performance and compliance, management systems and procedure, scope and boundaries of CSR reporting, targets 
and achievements and assurance of the report writing. Scores were given in the denomination of ' 1 ' or ' 0 ' depending upon the information available in the open sources.

\section{QUALITATIVE METHOD OF DATA COLLECTION}

Qualitative interviews were conducted with the top management officials of these 23 companies. A detailed questionnaire was presented sometimes individually and twice in the form of focus group interview. Interviews were conducted in the premises of these companies. There were total 26 respondents. The pertinent research question being their understanding of the concept of CSR and the way CSR activities are being communicated with their stakeholders. Respondents were made aware of the fact that the answers are being recorded. Having collected the information the next step was to process this information into data that would be easier to analyse. Transcription is the process that helps to convert the sound recording into written language for subsequent analysis. At this point it must be pointed out that the spoken word and written language are not the same thing. Differences lie in that the spoken word exhibits pitch, volume, pace, tone and emotions but this is lacking in the written format. As is customary, the audio recordings were transcribed verbatim using and combining two conventional methods. The secretarial or playscript method of transcription which concentrates solely on the words that have been spoken was used. The Jefferson transcription style was also used at times, as well as common symbols, to provide additional information over and above that provided by the secretarial transcript (Jefferson, 2004). The Jefferson style was needed because it was felt that by not indicating how words are said, the analyst would be steered to interpreting the words merely as they were written in formal language and that would fail to do justice to the data which would have lost most of its features. The Jefferson style would enable the researcher to capture the paralinguistic features, such as words accompanied with a nervous chuckle, groans or sighs $\left(\mathrm{O}^{`} \mathrm{Connel}\right.$ and Kwoal, 1995).

The NVivo software was chosen to interpret the data because it has a set of tools which can assist in the analysis of qualitative data. This software, developed by researchers, is designed to support researchers in varied ways to help them to work with their data. The software helps in managing the data by organizing and keeping track of the raw data files, interviews and other documentary sources. The software helps in creating character-based coding with the facility of rich formatted text and the provision to freely edit or write text without invalidating earlier coding. This software was chosen as it had the advantages of improved screen display, helped in rapid accessing of data through documents or retrieval of coded texts and easy identification of data in relation to source characteristics. The software has a minimum computer requirement and can be downloaded easily with the ready to type-in license number to activate the software. Once the coding process was completed it helped the researcher to save the data in a format that was convenient for future use (Bazeley et al., 2013).

The researchers assumed the position of a realist in relation to what the participants said in their interviews. Transcription had already familiarized the researchers with the data and provided an early push or stimulus towards analyse of the data. The process started at the onset with the researchers looking for meaning and issues of potential interest to the research topic. The researcher starts by identifying or examining the underlying ideas, assumptions and conceptualizations shaping the data (Braun \& Clarke, 2006). The codes were re-worked and new 
groups were formed with some of the previously non- fitting codes. The applicability of the themes was further checked against the selected extracts as well as with the entire set of data. The themes helped the researcher to gain some unanticipated insights into the data and also proved to be beneficial for both social as well as psychological interpretation of the data.

\section{DATA ANALYSIS}

The qualitative interviews began with inductive reasoning, during the process of which themes and categories emerged from the data collected. The very first theme that emerged from the research question on the understanding of the concept of CSR was "Charity Giving" or 'philanthropy". Most of the respondents associated corporate social responsibility with ad hoc donation of money, "we giving money whenever possible to some noble cause, there is no fixed time or date, but mainly during festivals" (Respondent B). The second theme that emerged from the qualitative interviews is "adhoc giving". The respondents agreed to the fact that companies do contribute to just and charitable causes but there are no well-crafted strategy to back those giving. No plan or campaign has been put to place to monitor and evaluate the outcome of charity giving. "Charity giving is mainly controlled by people whom you know and who comes to ask you for a favour. It is often your friends and family members who requests you to donate for a cause they are associated with. We hardly monitor such giving" (Respondent A). The third theme that emerged from analysing the transcript was "absence of communication strategy". Most respondents thought that these charity giving were a part of their tradition and they have been merely following what their predecessors have done. They believed that such contributions are best done in silence and communicating it to their stakeholders is not important. According to almost $70 \%$ of the respondents communicating such issues reflects them in a bad light and is not to be spoken about. They acknowledged that they are not aware of the fact that communication CSR activities could bring any business value to them.

\section{QUANTITATIVE DATA}

The form consisting of 46 criteria was divided amongst the top level employees of these 23 companies. Several follow up was needed to receive the answered forms. Out of 200 forms that were distributed only 68 were received $(n=68)$. The scorecard was also filled up by the researcher with the help of the information found in the open source of these companies, mainly the company website, annual report and their product or company brochure.

The parameters that were measured were as follows:

- CEO's statement

- Organizational Profile

- Scope of CSR activities

- Governance structure

- Key Impacts created by CSR activities

- Management Systems and Procedures

- Sustainability Related Policies

- Stakeholder Engagement

- Performance and Compliance

- Targets and Achievements 
- External Assurance

The quantitative data was tabulated with the help of SPSS software version 20. The tabulated data showed that almost 50\% $(n=49)$ couldn't answer questions pertaining to disclosure on governance structure of the company and individual responsibilities. $86 \%$ of the respondents did not have any sustainability related policies - disclosing policy commitments on economic and social issues. $35 \%$ of the respondents couldn't disclose any data on staff and members responsible for the environmental management programme. $85 \%$ of the company does not have any sustainability report hence there was no existence of external assurance on policies and practices.

Most of the companies revealed a very low CSR score, the average being 6-7 out of 46. The declaration made in the websites on CSR was inadequate and did not reveal much about the CSR health of the company. Most of the activities were altruistic in nature without generating any value creation towards the bottom line growth of the companies. None of these companies have embedded CSR in their business strategy. They are yet to realize the role of stakeholders for their business and often choose to ignore them in communicating their CSR activities. The websites are outdated and the information available on CSR is often a couple of years old. The booklet depicting CSR activities in a few companies were not written under any global guidelines and resemble picture albums glorifying un-coordinated philanthropic activities.

The findings both from the qualitative interviews and the quantitative data showed that much needs to be done as far as corporate social responsibility is concerned. In order to comply with the Companies Act of 2013, these companies needs to have a strategic goal while crafting their CSR policies. They need to be trained in order to understand the value of CSR and its business benefits.

\section{PROBLEMS RELATED TO THE STUDY}

The problems that the researchers faced in conducting both the quantitative and qualitative survey included obtaining willing participants for the survey. The officials were busy and were not interested in answering the questionnaire unless it was mandatory for them to do so. The concept of CSR still remains trivial for them and hence they were not willing to impart their views on the subject. The problem was resolved by repeating the exercise with several industries of similar nature.

The other problem was the location of these companies. All these companies were located in Eastern India and the study was not conducted with geographically dispersed companies. The result may have varied if the researchers had chosen other geographical areas of study.

\section{FURTHER SCOPE OF RESEARCH}

The research provides further scope of assessing the cultural dimensions of corporations engaging in CSR, their definition of CSR, their motives for engaging in CSR and how they plan to communicate CSR to their stakeholders in the future. 


\section{RECOMMENDATION AND CONCLUSION}

In order to make their CSR activities more strategic in nature companies are required to embed CSR in their business strategy and to use the framework laid down by Ministry of Corporate Affairs, Govt. Of India, National Voluntary Guidelines 2011 or the framework suggested by Global Reporting Initiatives (GRI) to disclose their CSR activities through a well written Sustainability Report.

Adequate training would be required to train the company officials on strategic CSR and business case for CSR and help can be sought from consultants who at least in the initial years can help the company. The philanthropic activities and the social issues need to be streamlined and strategic in nature so that it leads to a competitive advantage for the company. Embedding CSR in these companies has to start from the very beginning with a buy in from its stakeholders and should include various strategic components towards embedding CSR practices in the company and creating a sustainable competitive advantage of the firm

\section{REFERENCES}

[1] Campbell, John L. 2007. Why Would Corporations Behave in Socially Responsible Ways? An Institutional Theory of Corporate Social Responsibility. Academy of Management Review, Vol. 32, No. 3, pp. 946-967.

[2] Carroll, Archie B. 1999. Corporate Social Responsibility: Evolution of a Definitional Construct. Business \& Society, Vol. 38, No. 3, pp. 268-295.

[3] Elkington, John. 2004. Enter the Triple Bottom Line. In: Adrian Henriques \& Julie Richardson (Eds.). The Triple Bottom Line: Does it all add up? Assessing the sustainability of business and CSR, pp. 1-16. London: Earthscan.

[4] Fombrun, Charles J., Gardberg, Naomi A. \& Sever, Joy M. 2000. The Reputation Quotient: A Multi stakeholder ensure of corporate reputation. The Journal of Brand Management, Vol. 7, No. 4, pp. 241-255.

[5] Freeman, R. Edward \& Velamuri, S. Ramakrishna. 2006. A New Approach to CSR: Company Stakeholder Responsibility. In: Andrew Kakabadse, Mette Morsing \& Gilbert Lenssen (Eds.).Corporate Social Responsibility: Reconciling Aspiration with Application, pp. 245-354. New York: Palgrave Macmillan.

[6] Freeman, R. Edward. 1984. Strategic Management: A Stakeholder approach. Boston: Pitman.

[7] Hatch, Mary Jo \& Schult, Majken. 2003. Bringing the Corporation into Corporate Branding. European Journal of Marketing, Vol. 37, No. 7/8, pp. 1041-1064.

[8] Matten, Dirk \& Moon, Jeremy. 2005. A Conceptual Framework for Understanding CSR. In: André Habisch, Jan Jonker, Marina Wegner and René Schmidpeter (Eds.). Corporate Social Responsibility Across Europe, pp. 335-356. Berlin: Springer.

[9] Morsing, Mette. 2006. Corporate Social Responsibility as strategic auto-communication: on the role of external stakeholders for member identification. Business Ethics: A European Review, Vol. 15, No. 2, pp. 171-182.

[10] Aruna Das Gupta, Ananda Das Gupta, (2008) "Corporate social responsibility in India: towards a sane society?", Social Responsibility Journal, Vol. 4. 